\title{
PENGARUH PEMAPARAN UAP ANTI NYAMUK ELEKTRIK YANG MENGANDUNG ALLETHRIN TERHADAP BERAT DAN WARNA PARU-PARU TIKUS
}

\author{
Tri Pangesti Hayu W ${ }^{1}$, Ayly Soekanto ${ }^{2}$ \\ ${ }^{1}$ Mahasiswa Fakultas Kedokteran \\ ${ }^{2}$ Bagian Anatomi Fakultas Kedokteran \\ Universitas Wijaya Kusuma Surabaya \\ Email: aylysoekantodr@yahoo.com
}

\begin{abstract}
Abstrak
Paru-paru sebagai alat pertukaran udara berhubungan erat dengan keadaan lingkungan sekitar. Penggunaan anti nyamuk elektrik yang mengandung allethrin dalam jangka waktu tertentu dapat menimbulkan kelainan pada organ paru-paru.

Tujuan penelitian ini untuk mengetahui apakah pemaparan uap anti nyamuk elektrik yang mengandung allethrin berpengaruh terhadap berat dan warna paru-paru tikus. Penelitian bersifat eksperimental laboratorik. Tikus galur wistar jantan sebanyak 24 ekor dibagi dalam 4 kelompok, yaitu kelompok I kontrol (P0) tanpa pemaparan, kelompok II (P1) pemaparan 4 jam perhari, kelompok III (P2) pemaparan 6 jam perhari dan kelompok IV (P3) pemaparan 8 jam perhari. Hari ke 30 tikus diterminasi dan dilakukan pembedahan untuk pengambilan organ paru-paru. Dilakukan penimbangan berat paru-paru dan penilaian perubahan warna pada paru-paru tikus. Data yang diperoleh kemudian diolah dengan menggunakan Uji Anova untuk menganalisa berat, dan uji kruskal wallis untuk menganalisa perubahan warna, masingmasing dengan nilai signifikan $(\alpha<0,05)$.

Hasil uji Anova $(\alpha=0.004)$ dan Uji Kruskal Wallis $(\alpha=0,001)$, sehingga menunjukkan perbedaan yang bermakna antara keempat kelompok perlakuan.

Kesimpulan terdapat pengaruh pemaparan uap obat anti nyamuk elektrik yang mengandung allethrin terhadap berat dan warna paru-paru tikus. Pengaruh paru-paru tersebut dapat terjadi akibat adanya kolaps alveolus atau kolaps pada paru-paru.
\end{abstract}

Kata kunci: uap allethrin, berat badan, warna paru-paru tikus.

\section{THE ROLE OF FUMES EXPOSURE FROM ELECTRIC MOSQUITO REPELLENT CONTAINED ALLETHRIN AGAINST WEIGHT AND COLOUR OF THE RAT'S LUNGS}

\begin{abstract}
Lungs as place where the gases exchange inside the body is related to enviroment sorrounding. Usage of electric mosquito repellent that contained allethrin on certain period can inflict lung's abnormalities.
\end{abstract}


The aim to this research is to find the effect of fumes exposure from the electric mosquito repellent that contained allethrin to weight and colour of rat's lungs. The research was experimental laboratory. 24 male rats strain Wistar that devided into 4 groups, which were group 1 control (P0) without exposure, group $2(P 1)$ exposed 4 hours a day, group $3(P 2)$ exposed 6 hours a day and group 4 (P3) exposed 8 hours a day. In 30 th day, the rats terminated in the order to taken their lungs organ by operation. The purpose of taken the lungs was analyzed lung's weight and alteration of its colour. The acquired data process by Anova test for weight analysis, and Kruskal Wallis test for colour change analysis, respectively with significant value $(\alpha<0,05)$.

The result of anova test is $(\alpha=0.004)$ and kruskal wallis test is $(\alpha=0,001)$, that to mean there are significan differentiation in group.

Conclusion of this research : there was an effects of fumes exposure of electric mosquito repellent that contain allethrin against the weight and colour of the rat's lungs. That effect on the lungs occour because collaps of the alveolus or lungs.

Keywords : allethrin fumes, body weight, colour of the rat's lungs.

\section{PENDAHULUAN}

\begin{abstract}
Perkembangan teknologi yang semakin maju sejalan dengan perkembangan model anti nyamuk yang tersedia dipasaran. Salah satunya adalah bentuk elektrik yang mengandung allethrin. Anti nyamuk dalam bentuk elektrik tidak menimbulkan asap seperti anti nyamuk bakar, sehingga banyak masyarakat yang lebih tertarik, atau masyarakat menganggap anti nyamuk elektrik lebih aman dan efisien.
\end{abstract}

Allethrin atau C19H26O3 merupakan senyawa turunan dari pyrethroid dalam anti nyamuk. Zat ini banyak digunakan dalam racun pembasmi nyamuk sehingga memiliki resiko merusak kesehatan. Zat tersebut dapat masuk ke dalam tubuh melalui tiga cara, yaitu: termakan atau terminum bersama makanan atau minuman, dihirup dalam bentuk gas dan uap, langsung menuju paru-paru lalu masuk ke dalam aliran darah, atau terserap melalui kulit dengan tanpa terlebih dahulu menyebabkan luka pada kulit. Allethrin yang terakumulasi di dalam tubuh dapat membentuk radikal bebas ${ }^{1}$.

Zat-zat aktif yang terkandung dalam obat anti nyamuk elektrik bila digunakan secara rutin lambat laun dapat mempengaruhi dan menyebabkan kelainan pada organ-organ tubuh manusia, salah satunya adalah paru-paru ${ }^{2}$.

Paru-paru sebagai alat pernafasan berfungsi sebagai alat pertukaran udara (ventilasi). Paru-paru sebagai organ dalam tubuh berhubungan dengan dunia luar tentu memiliki resiko mengalami gangguan. 
Berdasarkan penelitian yang dilakukan Pertiwi dan Wahyuningsih (2011) pada 100 responden yang tersebar diwilayah Solo Raya ditemukan 94\% responden menggunakan insektisida rumah tangga untuk nyamuk, sebesar $15 \%$ pengguna bentuk elektrik, dengan dampak $62 \%$ mengalami gangguan pernapasan ${ }^{3}$.

Gangguan dan kerusakan pada struktur paru-paru timbul sebagai akibat pemaparan partikel-partikel berbahaya. Gangguan tersebut dapat diamati melalui perubahan berat dan warna paru-paru tikus setelah pemaparan anti nyamuk.

Tujuan khusus dari penelitian ini adalah menganalisis pengaruh lama pemaparan uap anti nyamuk elektrik yang mengandung allethrin selama 4, 6 dan 8 jam perhari terhadap berat paru-paru tikus dan menganalisis pengaruh lama pemaparan uap anti nyamuk elektrik allethrin selama 4, 6 dan 8 jam perhari terhadap warna paru-paru tikus.

\section{METODE}

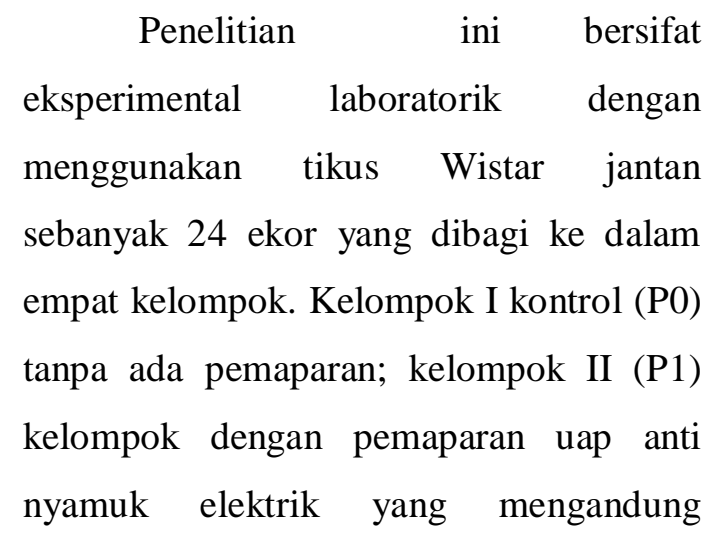

allethrin selama 4 jam perhari; kelompok III (P2) kelompok yang dipapar uap anti nyamuk elektrik yang mengandung allethrin selama 6 jam perhari; dan kelompok IV (P3) kelompok dengan pemaparan uap anti nyamuk elektrik yang mengandung allethrin selama pemaparan 8 jam perhari.

Tahapan pemaparan uap anti nyamuk elektrik yang mengandung allethrin dilakukan dengan terlebih dahulu menyiapkan kotak atau kandang tikus dengan ukuran (40 cm x $40 \mathrm{~cm}$ x $30 \mathrm{~cm}$ ). Kandang dibungkus dengan plastik transparan dan diberi lubang ventilasi kemudian anti nyamuk elektrik yang mengandung allethrin digantung dibagian bawah kandang dengan tujuan agar anti nyamuk tidak dijangkau oleh tikus tetapi masih berefek pada inhalasi tikus.

Setelah 30 hari tikus diterminasi, dengan cara dianestesi menggunakan eter dan dilakukan pembedahan untuk pengambilan paru-paru. Paru-paru diambil ditimbang kemudian diamati untuk melihat adanya perubahan warna.

\section{Lokasi dan Waktu Penelitian}

Penelitian di lakukan di Laboratorium Biokimia Fakultas Kedokteran Universitas Airlangga Surabaya pada bulan Juli - Agustus 2015. 


\section{Populasi dan Sampel}

Populasi dalam penelitian ini adalah tikus wistar jantan. Penentuan besar sampel dengan menggunakan rumus Federer ${ }^{4}$.

Besar sampel minimal yang diperlukan adalah 6 ekor tikus Wistar untuk setiap kelompok perlakuan, sehingga besar sampel total dalam penelitian ini adalah 24 ekor tikus dengan kriteria:

1. Kriteria Inklusi: Tikus Wistar berumur 60 hari dengan berat badan 150 gram, jantan, dan dalam keadaan sehat.

2. Kriteria Eksklusi:

Tikus sakit atau mengalami luka dan mati dalam perlakuan.

\section{Teknik Pemeriksaan Dan Pengukuran}

Teknik dari pemeriksaan berat paru -paru tikus dilakukan dengan penimbangan (gram), sedangkan untuk pemeriksaan atau pengamatan warna dilakukan setelah organ paru-paru direndam dalam formalin $10 \%$ selama 30 menit dalam suhu kamar. Dari hasil perubahan warna yang ada dianalisa dengan diberi skor sesuai kriteria ${ }^{5}$.

a) Skor 0: Tidak ada perubahan

b) Skor 1: Perubahan warna rendah

c) Skor 2: Perubahan warna sedang

d) Skor 3: Perubahan warna kuat

\section{Rancangan Analisis}

Uji Anova untuk menganalisa perubahan berat paru-paru tikus, dan uji Kruskal Wallis untuk menganalisa perubahan warna pada paru-paru tikus.

\section{HASIL PENELITIAN}

\section{Hasil Penimbangan Berat Paruparu (gram)}

Rata - rata berat paru-paru kelompok kontrol (P0) adalah 1,7767 gram, kelompok kedua (P1) 1,5600 gram, kelompok ketiga (P2) didapatkan1,4717 gram, dan kelompok keempat (P3) 1,3467 gram. Keseluruhan hasil penelitian dan nilai rata - rata berat paru-paru tikus pada masing - masing kelompok ( Tabel 1).

Tabel 1. Rerata Berat Paru-paru (gram) Tikus yang dipapar dengan anti nyamuk elektrik mengandung Alletherin

\begin{tabular}{c|l|l|l|l}
\hline NO & PO & P1 & P2 & P3 \\
\hline 1 & 2,15 & 1,47 & 1,30 & 1,40 \\
\hline 2 & 2,01 & 1,43 & 1,40 & 1,29 \\
\hline 3 & 1,57 & 1,71 & 1,50 & 1,57 \\
\hline 4 & 1,63 & 1,75 & 1,53 & 1,36 \\
\hline 5 & 1,70 & 1,40 & 1,32 & 1,25 \\
\hline 6 & 1,60 & 1,60 & 1,78 & 1,21 \\
\hline Total & 10,66 & 9,34 & 8,83 & 8,09 \\
\hline $\begin{array}{l}\text { Rata- } \\
\text { rata }\end{array}$ & $\mathbf{1 , 7 7 6 7}$ & $\mathbf{1 , 5 6 0 0}$ & $\mathbf{1 , 4 7 1 7}$ & $\mathbf{1 , 3 4 6 7}$ \\
\hline
\end{tabular}


Nilai rata-rata berat paru-paru tikus dari masing-masing kelompok diatas dapat dilihat pada Gambar 1.

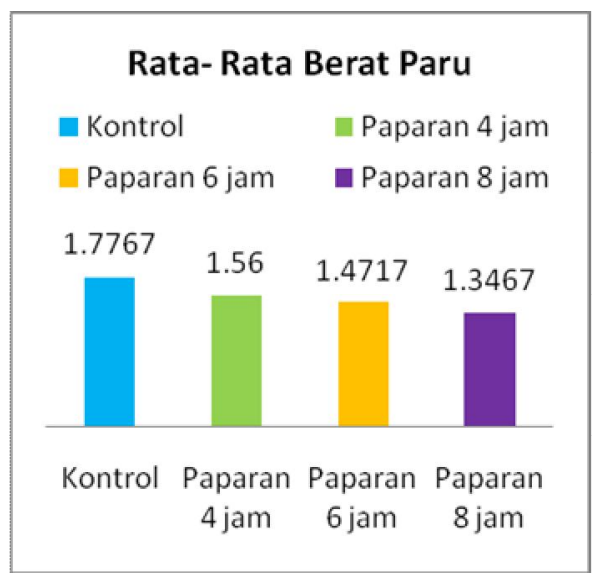

Gambar 1. Diagram Batang Rerata berat paru-paru Tikus dari masing-masing kelompok perlakuan

Grafik diatas menunjukkan bahwa secara rata - rata pemaparan uap anti nyamuk elektrik dapat mempengaruhi berat paru-paru tikus. Hal ini terlihat pada (Gambar 1).

Rata-rata berat paru-paru tertinggi terdapat pada kelompok kontrol dan terendah pada kelompok (P3) pemaparan 8 jam/hari.

\section{Hasil Penilaian Warna}

Pengamatan terhadap perubahan warna paru-paru tikus (Gambar 2). Data yang diperoleh merupakan data ordinal. Perubahan warna paru-paru tikus dibagi dalam 4 kategori. Keempat kategori tersebut adalah kelompok P0 tampak paru-paru berwarna coklat). Pada kelompok P1 perubahan warnanya rendah, tampak adanya bercak-bercak. Pada kelompok P2, terjadi perubahan warnanya sedang yaitu tampak warna merah terdapat pada satu lobus paru-paru. Pada kelompok P3 terjadi perubahan warna yang sangat kuat, warna merahnya jelas pada kedua lobus paru-paru.
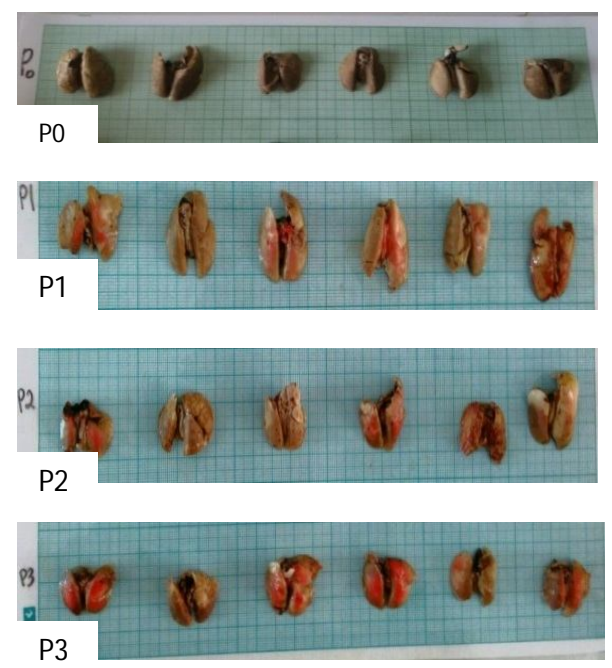

Gambar 2. Hasil Pengamatan Perubahan Warna Pada Paru-paru Tikus. 
Penilaian warna paru-paru tikus diukur dengan intensitas warna, dapat diamati pada Tabel 2. dan Gambar 3.

Tabel 2. Data Hasil Penilaian Warna Paruparu Tikus Pada Masing-Masing Kelompok

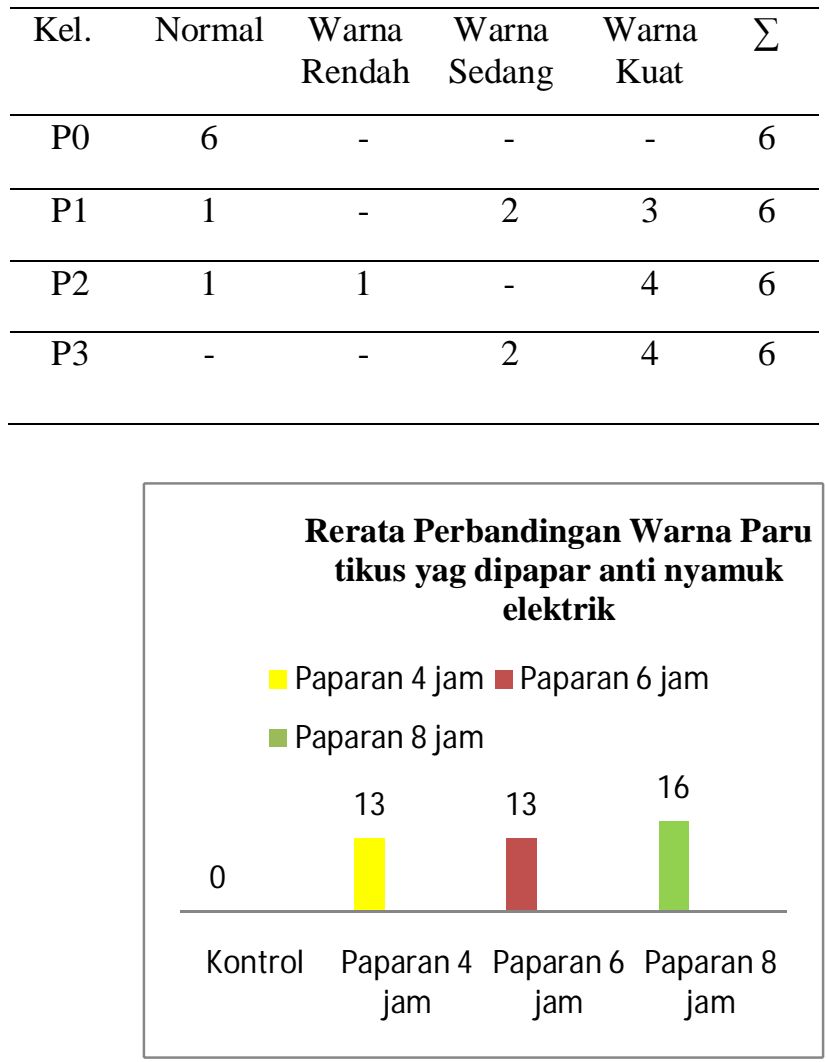

Gambar 3. Diagram Batang rata-rata Warna Paru-paru Tikus dari masing masing kelompok.

Gambar 3. pada diagram batang menunjukkan bahwa rata-rata paparan uap anti nyamuk elektrik dapat mempengaruhi warna paru-paru tikus. Hal ini terlihat pada grafik (P3) dengan lama pemaparan 8 jam, yaitu terjadi peningkatan perubahan warna pada paru-paru tikus.

\section{ANALISA DATA}

\section{Analisa Data Berat Paru-Paru}

Hasil Uji One Way Anova menunjukkan terdapat perbedaan yang bermakna antara kelompok kontrol dan kelompok pemaparan dengan hasil $\alpha=$ 0,004, dilanjutkan Uji post hoc (LSD) untuk mengetahui perbedaan yang bermakna antar kelompok (Tabel 3).

Tabel 3. Hasil Uji LSD

\begin{tabular}{|c|c|c|}
\hline (I) & $\begin{array}{c}(\mathrm{J}) \\
\text { nanaran }\end{array}$ & Mean \\
\hline $\begin{array}{l}\text { paparan } \\
\text { Kontrol }\end{array}$ & $\mathrm{P} 1$ & $\begin{array}{c}\text { Difference }(1-J) \\
21667^{*}\end{array}$ \\
\hline (P0) & $\mathrm{P} 2$ & ,30500* \\
\hline & P3 & ,43000* \\
\hline paparan & P0 &,$- 21667^{*}$ \\
\hline 4 jam & P2 & ,08833 \\
\hline (P1) & P3 & 21333 \\
\hline paparan & P0 &,$- 30500^{*}$ \\
\hline $6 \mathrm{jam}$ & P1 &,- 08833 \\
\hline (P2) & P3 & , 12500 \\
\hline paparan & P0 &,$- 43000^{*}$ \\
\hline 8 jam & P1 &,- 21333 \\
\hline (P3) & P2 &,- 12500 \\
\hline
\end{tabular}

*.The mean difference is significant at the 0.05 level.

Melalui Uji LSD menunjukkan antara P0 dengan P1 didapatkan $\alpha=0,05$ yang berarti terdapat perbedaan yang bermakna. Antara kelompok P0 dengan P2, $\alpha=0,008$ yang menunjukkan terdapat perbedaan yang bermakna, dan antara kelompok P0 dengan P3 didapatkan $\alpha=$ 0,001 sehingga dapat disimpulkan bahwa secara uji statistik pemaparan uap anti nyamuk elektrik yang mengandung alltherin menunjukkan ada pengaruh yang signifikan pada semua kelompok. 


\section{Analisa Data Warna}

Analisa data terhadap perubahan warna paru-paru tikus yang dipapar dengan anti nyamuk elektrik mengandung alltherin dengan Uji Kruskal Wallis didapatkan $\alpha=0,001(\alpha<0,05)$, hal ini menunjukkan bahwa terdapat perbedaan yang sangat signifikan antara kelompok P0 dengan P1, P2, P3.

Tabel 4. Hasil Uji Mann Whitney

\begin{tabular}{ccl}
\hline $\begin{array}{c}\text { Kelompok } \\
\text { yang } \\
\text { Dibanding- } \\
\text { kan }\end{array}$ & $\alpha(<0,05)$ & Signifikansi \\
\hline P0: P1 & 0,015 & Signifikan \\
\hline P0: P2 & 0,015 & Signifikan \\
\hline P0 : P3 & 0,002 & Signifikan \\
\hline P1 : P2 & 0,818 & $\begin{array}{l}\text { Tidak } \\
\text { Signifikan }\end{array}$ \\
\hline P1 : P3 & 0,589 & $\begin{array}{l}\text { Tidak } \\
\text { Signifikan }\end{array}$ \\
\hline P2 : P3 & 0,818 & $\begin{array}{l}\text { Tidak } \\
\text { Signifikan }\end{array}$ \\
\hline
\end{tabular}

Melalui Tabel 4 diatas dapat dilihat bahwa adanya perbedaan yang signifikan $\alpha$ $<0,05$, diantara $\mathrm{P} 0$ dengan $\mathrm{P} 1=0,015 ; \mathrm{P} 0$ dengan $\mathrm{P} 2=0,818 ; \mathrm{P} 1$ dengan $\mathrm{P} 3=$ 0,818, P0 dengan P3, sebaliknya pada kelompok P1 dan P2, P2 dan P3 tidak terdapat perbedaaan yang signifikan $\alpha>$ 0,05 .

\section{PEMBAHASAN}

\section{Pembahasan Berat Paru}

Hasil uji statistik Anova dan uji lanjutan LSD menunjukkan bahwa lama pemaparan menyebabkan terjadinya penurunan pada berat paru-paru tikus.

Hasil penelitian menunjukkan bahwa berat paru-paru tikus pada kelompok P3 mengalami penurunan berat pada organ paru-paru tikus. Hal ini dapat memberikan makna bahwa telah terjadi peningkatan aktivitas partikel partikel akibat paparan uap anti nyamuk elektrik terutama alletrin. Alletrin memiliki potensi untuk merusak dan menyebabkan inflamasi pada jaringan paru-paru, sehingga pada waktu tertentu dapat mengubah struktur dari organ.

Hasil penelitian ini dapat dilihat secara langsung pada nilai rata - rata berat paru-paru tikus sebelum dianalisa dengan uji statistik, dimana kelompok tikus yang mendapatkan pemaparan lebih lama yaitu 8 jam perhari mengalami penurunan berat paru-paru yang lebih rendah dibanding kelompok lain. Penurunan berat paru-paru tikus menunjukkan adanya aktivitas partikel-partikel yang terkandung dalam uap anti nyamuk elektrik, salah satunya adalah allethrin. allethrin memiliki potensi dalam merusak jaringan paru-paru atau menyebabkan inflamasi, sehingga dalam waktu tertentu pula paru-paru dapat mengalami perubahan struktur. 
Sesuai penelitian yang telah dilakukan oleh Andijayanti (2007) Paruparu merupakan organ tubuh yang sering mengalami kelainan patologi. Pemaparan partikel yang terkonsentrasi di udara dalam jangka pendek, dapat menginduksi terjadinya inflamasi paru-paru tikus ${ }^{6}$.

Bahan partikel berbahaya atau radikal bebas yang masuk dalam pernapasan dapat menimbulkan efek akut maupun kronis. Efek akut radikal bebas pada sistem pernafasan secara langsung dapat merusak sel-sel epitel saluran nafas terutama epitel alveoli atau merangsang terjadinya proses peradangan dan kerusakan pada jaringan paru-paru ${ }^{7}$.

Perubahan berat paru-paru tikus yang terjadi pada penelitian ini dapat disebabkan oleh bahan-bahan partikel berbahaya atau radikal bebas yang masuk ke dalam paru-paru akan menyebabkan gangguan pernapasan, inflamasi, kerusakan jaringan paru-paru, seperti alveolus yang mungkin mengalami kolaps.

Alveolus kolaps merupakan kondisi dimana udara dalam alveolus berkurang atau bahkan alveolus tidak mengandung udara, sehingga tidak dapat ikut serta di dalam pertukaran gas, hal tersebut dapat terjadi karena bronkus yang tersumbat dan pernapasan dangkal yang disebabkan minimnya oksigen yang tersedia. Kondisi ini mengakibatkan penurunan luas permukaan pada organ paru-paru proses difusi, dengan demikian kecepatan pernapasan menjadi berkurang. Alveolus kolaps dapat juga menyebabkan pengkerutan sebagian atau seluruh lobus paru-paru.

Sama seperti penelitian yang dilakukan oleh Retnowati dan Nugroho (2009) pada organ paruparu hewan sapi yang mengalami kolaps atau atelektasis ditemukan ukuran paru-paru lebih kecil dari ukuran normalnya 9 .

Adanya hasil data berat paru - paru yang didapat melalui penelitian eksperimental laboratorik dengan mengunakan tikus Wistar menggambarkan secara keseluruhan bahwa pemaparan uap anti nyamuk elektrik yang mengandung allethrin memberikan pengaruh terhadap penurunan berat paru-paru tikus. Hal tersebut dimungkinkan akibat terjadinya kolaps paru atau alveolus saja yang mengalami pengkerutan sehingga dapat mengurangi berat paru - paru tikus.

\section{Pembahasan Warna Paru Tikus}

Uji Kruskal Wallis dan uji lanjutan Mann Whitney menujukkan hasil bahwa ada perbedaan yang signifikan pada kelompok kontrol dan kelompok perlakuan, hal tersebut akibat lama pemaparan uap anti nyamuk elektrik pada kelompok perlakuan yang berbeda. 
Persamaan anti nyamuk ellektrik yang mengandung allethrin menggunakan media listrik menghasilkan uap dan gas allethrin. Allethrin merupakan jenis insektisida pengusir nyamuk yang juga mengandung zat radikal bebas.

Penumpukan dari radikal bebas ini menyebabkan makrofag alveolar tidak dapat berfungsi dengan baik membuang partikel yang masuk ke dalam paru-paru sehingga meningkatkan resiko terjadinya infeksi dan inflamasi dalam paru-paru ${ }^{10}$.

Secara patologis makroskopis paruparu mengalami inflamasi. . Hal ini memberi makna bahwa telah terjadi kerusakan pada jaringan seperti alveolus kolaps. Kolaps paru-paru atau kolaps alveolus ditandai dengan penurunan luas permukaan dan pengkerutan paru-paru. Selain itu juga terjadi perubahan warna pada paru - paru. Warnanya adalah menjadi merah ${ }^{11}$.

Penyebab utama terjadinya kolaps paru-paru atau alveolus adalah adanya penyumbatan pada bronkus. Bronkus merupakan percabangan utama dari trakea yang langsung menuju ke paru-paru. Penyumbatan dapat pula terjadi pada saluran pernafasan yang lebih kecil. Beberapa faktor penyumbat yang diakibatkan oleh gumpalan lendir, tumor, benda asing atau zat-zat yang terhisap ke dalam bronkus ${ }^{12}$.
Pernapasan yang tersumbat mengakibatkan udara di dalam alveoli akan terserap kedalam aliran darah sehingga alveoli akan menciut. Jaringan paru-paru yang mengkerut akan terisi dengan berbagai eksudat salah satunya darah terakumulasi dan terjebak didalam alveoli yang sudah tampak mengalami kerusakan ${ }^{9}$.

Hasil pengamatan warna paru-paru tikus didapatkan bahwa kelompok tikus (P3) dengan pemaparan lebih lama (selama 8 jam perhari) memiliki rata - rata perubahan warna lebih tinggi dibanding kelompok lain, akan tetapi pemaparan 4 jam dan 6 jam perhari memiliki rata rata perubahan warna yang sama. Sebaliknya pada kelompok kontrol tidak terjadi perubahan warna. Perubahan warna menjadi merah pada penelitian ini dapat terjadi akibat alveoli yang rusak masih mengandung sisa-sisa darah yang terjebak atau terakumulasi, sedangkan bercak bercak hitam pada bagian paru-paru dimungkinkan akibat adanya pembuluh darah yang pecah ataupun jaringan pada paru-paru yang kekurangan oksigen. Sehingga dalam penelitian ini dapat disimpulkan bahwa pemaparan uap obat nyamuk elektrik yang mengandung allethrin berpengaruh terhadap warna paru-paru tikus. 


\section{KESIMPULAN}

Kesimpulan dari penelitian ini adalah sebagai berikut:

1. Pemaparan anti nyamuk elektrik yang mengandung allethrin dapat menurunkan berat da nmengubah warna organ paru-paru pada tikus.

2. Penurunan berat dan peru bahan warna tertinggi terdapat pada kelompok P3.

3. Perubahan berat dan warna paruparu tikus pada penelitian ini diakibatkan terjadinya kolaps alveolus atau kolaps paru-paru.

\section{SARAN}

1. Kandang penelitian sebaiknya perlu dirancang khusus agar pemaparan uap anti nyamuknya lebih maksimal.

2. Perlu dilakukan pemeriksaan lebih lanjut melalui sediaan preparat untuk melihat histopatologis terjadinya kolaps alveolus atau kolaps paru-paru lebih akurat dan diamati dibawah mikroskop.

3. Sebaiknya dilakukan penelitian dengan pemaparan anti nyamuk elektrik yang mengandung alletrin yang lebih lama untuk melihat efek sampingnya terhadap organ organ tikus lainnya.

\section{DAFTAR PUSTAKA}

1. Wahyuningsih, S., 2009. Pengaruh Vitamin C Dan E Terhadap Jumlah Erytrosit dan Kadar Hemoglobin Darah Tikus Putih Yang Dijejas Antinyamuk Elektrik, Fakultas MIPA Universitas Negeri Semarang, hal. 1.

2. Ariani, R., Kurniati, R., dan Rahmawati,S., 2012. Pengaruh Pemakaian Obat Nyamuk Elektrik Berbahan Aktif D-Allethrin Terhadap Sel Darah Tikus Spargue Dawley (mus musculus L), Jurusan Biologi FMIPA Universitas Mulawarman, hal. 1-3.

3. Pertiwi, G., dan Wahyuningsih, Y. S., 2011. Bahaya Obat Nyamuk Dan Cara Penanggulangannya, Media publikasi artikel Ekologikal Studies Programme, Surakarta, hal. 1.

4. Rizki, J. G., 2009. Efek Susu Kacang Kedelai Terhadap Kadar Asam Urat Darah Tikus Putih Jantan Yang Di induksi Kalium Oksalat, Fakultas Matematika Dan Ilmu Pengetahuan Alam Program Studi Farmasi, Universitas Indonesia, hal.52.

5. Novak M, Madej JA and Dziegeil P., 2007. Intensity of Cox 2 expression in Cell of Soft Tissue Fibro-sarcomas in Dog As Related to Grade of Tumor malignation. Bull Vet inst Pulawy. hal. 9.

6. Andijayanti, A. E., 2007. Pengaruh Asap Pelelehan Lilin Batik (Malam) Terhadap Struktur Histologis Trakea dan Alveoli Pulmo, Jumlah Eritrosit Serta Kadar Hemoglobin Mencit (mus musculus), Universitas Sebelas Maret, hal. 30 . 
7. Muliarta, 2008. Perbedaan Nilai Fungsi Paru Pengelas Pada Awal Shift Kerja Dan Cross - Week Di Denpasar Selatan, Bagian Fisiologi Fakultas Kedokteran, Universitas Udayana J1. Sudirman Denpasar, hal. 4.

8. Crowin, E., 2009. Buku saku patofisiologi. Jakarta: EGC.

9. Retno, Y., dan Nugroho T., 2009. Pemeriksaan Mikroba dan Patologi Organ Paru-Paru SapiI yang Mengalami Pneumonia Di Kota Gorontalo, Fakultas Matematika dan Ilmu Pengetahuan Alam (MIPA), Universitas Negeri Gorontalo, hal. 5
10. Larasati, S. A., 2010. Pengaruh Pemberian Jus Pepaya (Carica papaya) Terhadap Kerusakan Histologis Alveolus Paru Mencit Yang Dipapar Asap Rokok, Faakultas Kedokteran Sebelas Maret. Surakarata.

11. Soemantri, I, 2007. Asuhan Keperawatan pada Pasien dengan Gangguan Sistem Pernafasan, Edisi Pertama, Salemba medika, Jakarta, hal. 8.

12. Fox, J.G., Anderson, L.C., Loew, F.M., dan Quimby, F.W., 2002. Laboratory Animal Medicine. Seconf Edition. Academic Press. San diego, California. USA.

Reviewer

Dr. Dorta Simamora, M.Si. 